\title{
KNOWLEDGE, ATTITUDES AND HABITS REGARDING ORAL HEALTH IN FIRST- AND FINAL-YEAR DENTAL STUDENTS
}

\author{
Mia Lujo ${ }^{1}$, Marko Meštrović ${ }^{1}$, Ana Ivanišević Malčić ${ }^{2}$ Zoran Karlović \\ Jurica Matijević ${ }^{2}$ and Silvana Jukić ${ }^{2}$ \\ ${ }^{1}$ Sixth-year dental student; ${ }^{2}$ Department of Endodontics and Restorative Dentistry, \\ School of Dental Medicine, University of Zagreb, Zagreb, Croatia
}

\begin{abstract}
SUMMARY - The purpose of the research was to compare oral health behavior and plaque indices between Croatian first-year and final-year dental students. Therefore, $46.9 \%$ of first-year and $47 \%$ of final-year dental students were surveyed using the Hiroshima University Dental Behavior Inventory (HU-DBI) questionnaire and had their plaque indices determined. Descriptive statistics analysis, nonparametric tests, and correlation analysis were performed $(\mathrm{p}<0.05)$. Sixth-year students had a significantly better mean HU-DBI score (8.06) than first-year students (6.45). Significantly more firstyear students thought that they could not help having false teeth at their old age $(\mathrm{p}=0.007)$, had never been taught professionally how to brush $(\mathrm{p}=0.019)$, and used a toothbrush with hard bristles $(\mathrm{p}=0.001)$. Significantly more final-year students brushed each of their teeth carefully $(\mathrm{p}=0.008)$, thought they could clean their teeth well without using tooth paste $(\mathrm{p}=0.000)$, used a dye to see how clean their teeth were $(\mathrm{p}=0.002)$, and had their dentist telling them they brushed very well $(\mathrm{p}=0.028)$. Plaque index values were significantly lower $(\mathrm{p}<0.05)$ among first-year $(7.94 \pm 0.72)$ than among final-year $(9.13 \pm 0.77)$ students. With advancement in dental training, oral health attitudes improved, but the level of dental students' oral hygiene decreased.
\end{abstract}

Key words: Students, dental; Oral health; Surveys and questionnaires; Dental plaque index

\section{Introduction}

Oral diseases such as dental caries and periodontal disease present significant public health problems worldwide, and a strong need for public oral health promotion and organized efforts in improving oral health behavior has been recognized by the World Health Organization $(\mathrm{WHO})^{1}$. The reported decaymissing-filling-tooth (DMFT) index for 12-year-olds in Croatia was 3.5, which puts this newly joined European Union member on the list of countries that have

\footnotetext{
Correspondence to: Ana Ivanišević Malčić, DMD, PhD, Department of Endodontics and Restorative Dentistry, School of Dental Medicine, University of Zagreb, Gundulićeva 5, HR-10000 Zagreb, Croatia

E-mail: amalcicivan@gmail.com

Received November 19, 2014, accepted October 16, 2015
}

not achieved the WHO Goal 2000 of a DMFT index less than 3.0 for 12 -year-olds ${ }^{2}$.A very high prevalence of caries and periodontal diseases in adult Croatian population has also been reported ${ }^{3}$. The presence of microbial biofilm, i.e. plaque on teeth, is the key factor for the development of caries and periodontal diseases, and if regularly removed, the risk for the development of the mentioned diseases is considerably reduced ${ }^{4}$. The relationship between poor oral hygiene and some serious systemic conditions has been reported ${ }^{5}$.The population motivation and education on proper oral hygiene is therefore of utmost importance, and dental health professionals have an important role in improving the level of oral health education. It is thus needed that dental students during their preclinical and clinical studies receive education regarding oral health and challenges which dental profession faces in their 
population, so they can focus on the prevention rather than treatment, and to educate and motivate their future patients to improve their oral health behavior ${ }^{6,7}$.

It has been reported that dental students' oral health attitudes and behavior differ among countries $^{8-12}$ and among preclinical and clinical dental students ${ }^{7,13-17}$. There were certain suggestions and efforts made to standardize undergraduate dental education worldwide, including education on oral health promotion $^{7,8}$. In that sense, the Hiroshima University Dental Behavior Inventory (HU-DBI) methodological instrument is a very valuable tool enabling comparison of dental students' oral health behavior in different countries following different curricula ${ }^{8}$. Little is known about the oral health behavior of Croatian dental students and the influence of educational training on their oral health regimes, attitudes and knowledge. First-year dental students in Croatia take basic medical science courses. Starting from the second year, they take cariology and restorative dentistry, and from the third year oral hygiene and periodontology courses. Until recently, there was no specific course on oral health behavior in the curriculum, and the subject was taught within cariology, restorative dentistry, pediatric dentistry, periodontology and public health courses.

The objective of this study was to compare the firstyear and the final (sixth)-year dental students at $\mathrm{Za}$ greb University regarding oral health behavior using the HU-DBI, and to estimate the influence of dental training on the oral care regime by determining plaque index as an indicator of the present oral hygiene level, using the modified Greene-Vermillion method ${ }^{18}$.

\section{Subjects and Methods}

The research was approved by the Ethics Committee of the School of Dental Medicine, Zagreb University, and Administration for Secondary Education of the Ministry of Science, Education and Sports of the Republic of Croatia (Class 602-01/11-01/00009, Register No. 533-09-11-0004).

Sixty-two first-year dentistry students (accounting for $46.9 \%)$ and 47 (47.5\%) sixth-year dentistry students aged between 18 and 26 years participated in the research after having signed the informed consent form. Before conducting the research, the linguistic equivalence study was done. In short, the HU-DBI that was to be used in the first part of the research was translated by four bilingual dental medicine doctors independently. The translations were discussed and harmonized. The Croatian text was then back-translated into English by an English language teacher who had not seen the original text in English. Comparison with the original English version was done to check if they matched. The linguistic equivalence validation of English and Croatian versions was tested on a sample of eight bilingual fourth-year dental students. Cohen's kappa was used to test item agreement between the two language versions. The strength of agreement is reflected by the calculated kappa value: fair (0.21$0.40)$, moderate $(0.41-0.60)$, substantial (0.61-0.80), and almost perfect $(0.81-1.0)^{6}$. Kappa coefficients for the twenty HU-DBI question items ranged from 0.67 to 1.0 , which suggested that the Croatian version of the HU-DBI questionnaire was suitable for calculating scores that would be comparable to the ones obtained using English version of the questionnaire.

The Croatian version of the questionnaire regarding oral health attitudes and habits in tooth brushing was then distributed among students-participants and they filled it in. The questionnaire consisted of $20 \mathrm{di}-$ chotomous (agree-disagree) questions. On calculating the results, one point was added if the answer was either agree or disagree, depending on the question (see Table 1). The highest possible score equaled 12. A higher score signified better knowledge, attitudes and habits regarding oral health. The HU-DBI questionnaire was developed by Kawamura, and it has been reported to have good test-retest reliability in a particular population tested ${ }^{11,12}$. Also, it has been reported to be reliable in cross-cultural comparisons ${ }^{16,19}$.

In the second part of the research, plaque levels were determined in each participant using the modified Greene-Vermillion method ${ }^{18}$ and plaque test (Ivoclar Vivadent AG, Schaan, Liechtenstein). Dental arches were divided into sextants, three per jaw. Plaque indices were measured on vestibular and oral sides, and the highest plaque index in a sextant was recorded. Plaque index value 0 was recorded if there was no plaque in the sextant, 1 where there was less than onethird of a tooth surface covered with plaque, 2 where more than one-third and less than two-thirds of a tooth surface was covered with plaque, and 3 where more than two-thirds of a tooth surface was covered with plaque. The recordings of plaque indices were 
Table 1. Distribution of answers to particular Hiroshima University Dental Behavior Inventory (HU-DBI) questionnaire items by first-year and sixth (final)-year dental students (the groups of students were compared using Mann Whitney U test)

\begin{tabular}{|c|c|c|c|c|c|}
\hline \multicolumn{2}{|l|}{ Question } & $\begin{array}{l}1^{\text {st }} \text { year } \\
\mathrm{n}(\%)\end{array}$ & $\begin{array}{l}6^{\text {th }} \text { year } \\
\mathrm{n}(\%)\end{array}$ & $\begin{array}{l}\text { Total } \\
\mathrm{N}(\%)\end{array}$ & $\mathrm{p}$-value \\
\hline \multirow{2}{*}{$\begin{array}{l}\text { 1. I don't worry much about visiting the } \\
\text { dentist. }\end{array}$} & A & $7(11.5 \%)$ & $7(14.9 \%)$ & $14(13.0 \%)$ & \multirow[t]{2}{*}{0.602} \\
\hline & $\mathrm{D}$ & $54(88.5 \%)$ & $40(85.1 \%)$ & $94(87.0 \%)$ & \\
\hline \multirow{2}{*}{$\begin{array}{l}\text { 2. My gums tend to bleed when I brush my } \\
\text { teeth. (D) }\end{array}$} & A & $4(6.5 \%)$ & $1(2.1 \%)$ & $5(4.6 \%)$ & \multirow[t]{2}{*}{0.287} \\
\hline & $\mathrm{D}$ & $58(93.5 \%)$ & $46(97.9 \%)$ & $104(95.4 \%)$ & \\
\hline \multirow[t]{2}{*}{ 3. I worry about the color of my teeth. } & A & $3(4.9 \%)$ & $2(4.3 \%)$ & $5(4.6 \%)$ & \multirow[t]{2}{*}{0.872} \\
\hline & $\mathrm{D}$ & $58(95.1 \%)$ & $45(95.7 \%)$ & $103(95.4 \%)$ & \\
\hline \multirow{2}{*}{$\begin{array}{l}\text { 4. I have noticed some white sticky deposits } \\
\text { on my teeth. (A) }\end{array}$} & A & $2(3.3 \%)$ & $6(12.8 \%)$ & $8(7.4 \%)$ & \multirow[t]{2}{*}{0.063} \\
\hline & $\mathrm{D}$ & $59(96.7 \%)$ & $41(87.2 \%)$ & $100(92.6 \%)$ & \\
\hline \multirow[t]{2}{*}{ 5. I use a child sized toothbrush. } & A & $0(0.0 \%)$ & $0(0.0 \%)$ & $0(0.0 \%)$ & \multirow[t]{2}{*}{1.000} \\
\hline & $\mathrm{D}$ & $61(100.0 \%)$ & $47(100.0 \%)$ & $108(100.0 \%)$ & \\
\hline \multirow{2}{*}{$\begin{array}{l}\text { 6. I think that I cannot help having false teeth } \\
\text { when I am old. (D) }\end{array}$} & A & $24(38.7 \%)$ & $7(14.9 \%)$ & $31(28.4 \%)$ & \multirow[t]{2}{*}{$0.007^{*}$} \\
\hline & $\mathrm{D}$ & $38(61.3 \%)$ & $40(85.1 \%)$ & $78(71.6 \%)$ & \\
\hline \multirow[t]{2}{*}{ 7. I am bothered by the color of my gums. } & A & $6(9.8 \%)$ & $4(8.5 \%)$ & $10(9.3 \%)$ & \multirow[t]{2}{*}{0.815} \\
\hline & $\mathrm{D}$ & $55(90.2 \%)$ & $43(91.5 \%)$ & $98(90.7 \%)$ & \\
\hline \multirow{2}{*}{$\begin{array}{l}\text { 8. I think my teeth are getting worse despite } \\
\text { my daily brushing. (D) }\end{array}$} & A & $9(15.0 \%)$ & $4(8.5 \%)$ & $13(12.1 \%)$ & \multirow[t]{2}{*}{0.310} \\
\hline & $\mathrm{D}$ & $51(85.0 \%)$ & $43(91.5 \%)$ & $94(87.9 \%)$ & \\
\hline \multirow[t]{2}{*}{ 9. I brush each of my teeth carefully. (A) } & A & $25(40.3 \%)$ & $31(66.0 \%)$ & $56(51.4 \%)$ & \multirow[t]{2}{*}{$0.008^{*}$} \\
\hline & $\mathrm{D}$ & $37(59.7 \%)$ & $16(34.0 \%)$ & $53(48.6 \%)$ & \\
\hline \multirow{2}{*}{$\begin{array}{l}\text { 10. I have never been taught professionally } \\
\text { how to brush. (D) }\end{array}$} & A & $12(19.7 \%)$ & $2(4.3 \%)$ & $14(13.0 \%)$ & \multirow[t]{2}{*}{$0.019^{*}$} \\
\hline & $\mathrm{D}$ & $49(80.3 \%)$ & $45(95.7 \%)$ & $94(87.0 \%)$ & \\
\hline \multirow{2}{*}{$\begin{array}{l}\text { 11. I think I can clean my teeth well without } \\
\text { using tooth paste. (A) }\end{array}$} & A & $6(9.8 \%)$ & $19(40.4 \%)$ & $25(23.1 \%)$ & \multirow[t]{2}{*}{$0.000^{*}$} \\
\hline & $\mathrm{D}$ & $55(90.2 \%)$ & $28(59.6 \%)$ & $83(76.9 \%)$ & \\
\hline \multirow{2}{*}{$\begin{array}{l}\text { 12. I often check my teeth in a mirror after } \\
\text { brushing. (A) }\end{array}$} & A & $40(65.6 \%)$ & $35(74.5 \%)$ & $75(69.4 \%)$ & \multirow[t]{2}{*}{0.322} \\
\hline & $\mathrm{D}$ & $21(34.4 \%)$ & $12(25.5 \%)$ & $33(30.6 \%)$ & \\
\hline 13. I worry about having a bad breath. & A & $8(13.1 \%)$ & $2(4.3 \%)$ & $10(9.3 \%)$ & 0.117 \\
\hline & $\mathrm{D}$ & $53(86.9 \%)$ & $45(95.7 \%)$ & $98(90.7 \%)$ & \\
\hline 14. It is impossible to prevent gum disease with & A & $10(16.4 \%)$ & $4(8.5 \%)$ & $14(13.0 \%)$ & 0.229 \\
\hline tooth brushing alone. (D) & $\mathrm{D}$ & $51(83.6 \%)$ & $43(51.5 \%)$ & $94(87.0 \%)$ & \\
\hline 15. I put off going to the dentist until I have a & A & $7(11.5 \%)$ & $4(8.5 \%)$ & $11(10.2 \%)$ & 0.615 \\
\hline toothache. (D) & $\mathrm{D}$ & $54(88.5 \%)$ & $43(91.5 \%)$ & $97(89.7 \%)$ & \\
\hline 16. I have used a dye to see how clean my teeth & A & $10(16.1 \%)$ & $20(42.6 \%)$ & $30(27.5 \%)$ & $0.002^{*}$ \\
\hline are. (A) & $\mathrm{D}$ & $52(83.9 \%)$ & $27(57.4 \%)$ & $79(72.5 \%)$ & \\
\hline 17. I use a toothbrush which has hard bristles. & A & $19(30.6 \%)$ & $2(4.3 \%)$ & $21(19.3 \%)$ & $0.001^{*}$ \\
\hline & $\mathrm{D}$ & $43(69.4 \%)$ & $45(95.7 \%)$ & $88(80.7 \%)$ & \\
\hline 18. I don't feel I've brushed well unless I brush & A & $17(27.4 \%)$ & $8(17.0 \%)$ & $25(22.9 \%)$ & 0.203 \\
\hline with strong strokes. & $\mathrm{D}$ & $45(72.6 \%)$ & $39(83.0 \%)$ & $84(77.1 \%)$ & \\
\hline 19. I feel I sometimes take too much time to & A & $11(17.7 \%)$ & $9(19.1 \%)$ & $20(18.3 \%)$ & 0.852 \\
\hline brush my teeth. (A) & $\mathrm{D}$ & $51(82.3 \%)$ & $38(80.9 \%)$ & $89(81.7 \%)$ & \\
\hline 20. I have had my dentist tell me that I brush & A & $25(40.3 \%)$ & $29(61.7 \%)$ & $54(49.5 \%)$ & $0.028^{*}$ \\
\hline very well. & $\mathrm{D}$ & $37(59.7 \%)$ & $18(38.3 \%)$ & $55(50.5 \%)$ & \\
\hline HU-DBI total & & & & & 0.000 \\
\hline
\end{tabular}

HU-DBI score calculation: A - one point for each agree answer, D - one point for each disagree answer; *statistically significant difference $(\mathrm{p}<0.05)$ 
done at the School of Dental Medicine, University of Zagreb. In plaque index recordings, Plaque Test disclosing liquid (Ivoclar Vivadent AG, Schaan, Liechtenstein), dental mirror and dental curing unit Bluephase C8 (Ivoclar Vivadent AG, Schaan, Liechtenstein) were used. After application of the Plaque Test and washing it out with water, plaque was visualized under blue LED curing unit light under which it fluoresced. This method enables invisibility of plaque layers after the examination thus avoiding aesthetic problems. All the participants in the research were examined by two examiners (ML and MM). The HU-DBI questionnaire results and clinical plaque recordings were entered into a computer database (Google docs) and coded using MS Excel (Microsoft, Redmond, WA, USA) software. Descriptive statistics analysis, nonparametric tests (Mann Whitney test) and correlation analysis at the level of significance $\mathrm{p}<0.05$ were used to evaluate differences in the distribution of all variables in HU-DBI survey, and oral hygiene level by the stage of education, i.e. between the first- and finalyear students. After univariate analyses by comparing the answers of the first- and final-year students, binary logistic regression was performed where the stage of dental education was dependent variable. Null hypothesis that the regression coefficients were zero was tested using Wald statistics. The ability of the model to distinguish between the first-year and final-year students was assessed using Nagelkerke's R2 statistics. Statistical analysis was done using SPSS ver. 17 software (IBM, Armonk, NY, USA).

\section{Results}

Altogether 109 students participated in the research: sixty-two (46.9\%) first-year students and fortyseven (47\%) sixth-year students. Table 1 shows distribution of answers to twenty HU-DBI questionnaire items. Statistical analysis showed significant difference between the first-year and sixth-year dental students in total HU-DBI score, which was significantly higher for sixth-year dental students (Mann Whitney U test, $\mathrm{Z}=-5.079, \mathrm{p}=0.0001)$. The mean HU-DBI score was $8.06 \pm 0.22$ for sixth-year students and $6.45 \pm 0.18$ for first-year students. Figure 1 illustrates total HU-DBI questionnaire scores for the two groups of students.

The mean values of plaque indices per sextants and jaws for first-year and sixth-year students are shown in

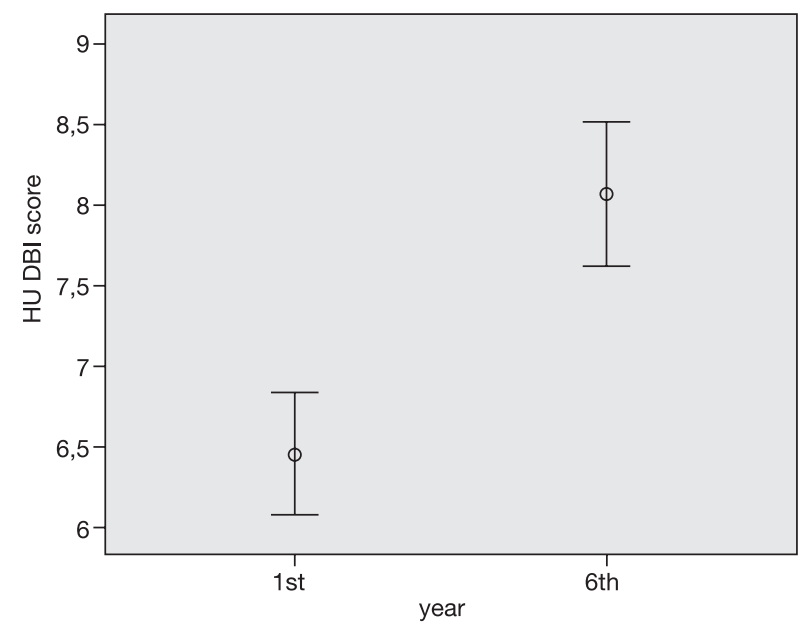

Fig. 1. Comparison of Hiroshima University Dental Behavior Inventory (HU-DBI) scores between first-year and sixth-year dental students at the School of Dental Medicine, University of Zagreb ( $p<0.05)$.

Figures 2 and 3. Total plaque index for first-year students $(7.94 \pm 0.72)$ was significantly lower than for sixth-year students $(9.13 \pm 0.77)$. Final-year students had more plaque than first-year students in four sextants. The difference was statistically significant for lower frontal sextant (Mann-Whitney $U=1134.500$, $\mathrm{Z}=-2.069, \mathrm{p}=0.039)$ and lower left sextant (MannWhitney U=1017.000, $Z=-2.771, \mathrm{p}=0.006$ ).

The estimated coefficients and related statistics from the binary logistic regression model that predicts group membership (Wald backward stepwise method) are listed in Table 2. The sixth-year students were more likely to think that they could clean their teeth well without using a toothpaste and used a dye to see how clean their teeth were, while first-year students were more likely to use a toothbrush with hard bristles. The Nagelkerke $R^{2}$ statistics was 0.514 , meaning that $51 \%$ of the variance was explained by the regression model.

\section{Discussion}

A number of studies dealing with self-evaluation of oral health and oral hygiene habits were conducted among different populations, and HU-DBI was one of the most frequently used methodologies, which enables comparisons between different countries, cultures and educational systems ${ }^{8}$. We found that the overall mean HU-DBI score of the final-year students was signifi- 

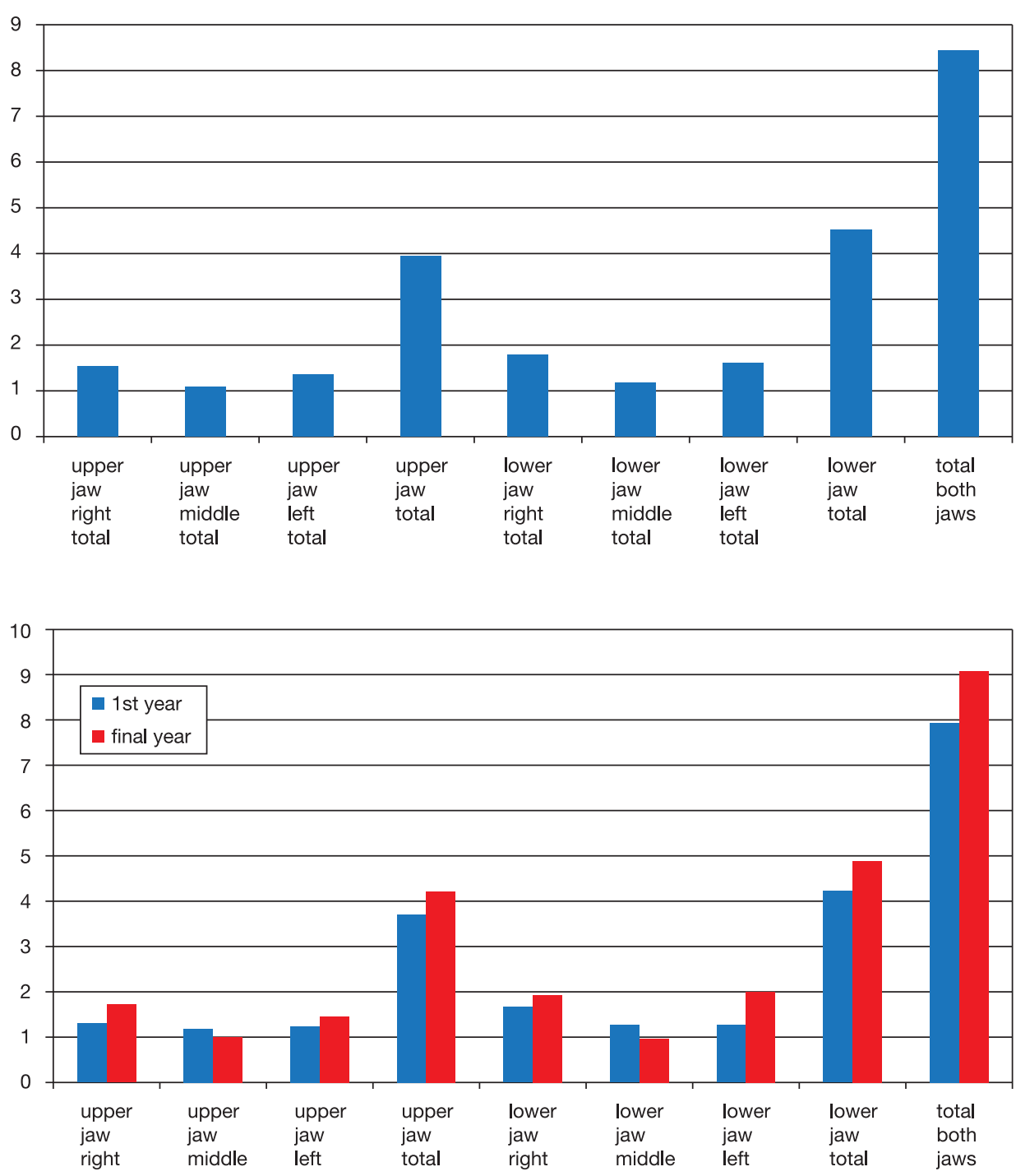

Fig. 2. Mean plaque index values for the whole student population studied.

Fig. 3. Mean plaque index values for first-year and final-year students. cantly higher than that of the first-year students. The same pattern was observed in other countries where dental students at different levels of their training were compared regarding oral health behavior and attitudes ${ }^{7,10,13-17}$. The total HU-DBI score of the final-year dental students in Croatia was 8.06 and exceeded the values of the mean dental students' scores in Britain (7.33), Turkey (6.53 \pm 1.99$)$, Greece (6.86 \pm 1.83$)$, China (5.07), and Japan $(7.40 \pm 2.55)^{10,16,17}$. This slightly better score could be attributed to the sixth study year. HU-DBI score for the first-year students (6.45) is, however, below the reported mean values for dental students in the mentioned countries, and is nearest to the values reported for Greece and Turkey which are, of the mentioned, geographically nearest.
When analyzing particular items, our results showed that significantly more first-year students thought that they could not help having false teeth when growing old, significantly more of them had never been taught professionally how to brush, and also used a toothbrush with hard bristles. Significantly more final-year students brushed each of their teeth carefully, thought they could clean their teeth well without using tooth paste, used a dye to see how clean their teeth were, and had their dentist telling them that they brushed very well. Domitrescu et al. ${ }^{14}$ found that Romanian students at higher years flossed regularly more likely, and similar to our study, used a toothbrush with hard bristles. It has been reported that preclinical students in Turkey, Jordan and Greece put off 
Table 2. Binary logistic regression - backward stepwise method (Wald)

\begin{tabular}{|c|c|c|c|c|c|c|}
\hline Question & B & S.E. & Wald & $\mathrm{df}$ & Sig. & $\operatorname{Exp}(\mathrm{B})$ \\
\hline $\begin{array}{l}\text { 11. I think I can clean my teeth well without } \\
\text { using tooth paste. (A) }\end{array}$ & 1.495 & 0.744 & 4.032 & 1 & 0.045 & 4.457 \\
\hline $\begin{array}{l}\text { 16. I have used a dye to see how clean my } \\
\text { teeth are. (A) }\end{array}$ & 1.764 & 0.683 & 6.674 & 1 & 0.010 & 5.837 \\
\hline 17. I use a toothbrush which has hard bristles. & -2.362 & 0.945 & 6.246 & 1 & 0.012 & 0.094 \\
\hline Constant & -0.926 & 0.687 & 1.817 & 1 & 0.178 & 0.396 \\
\hline
\end{tabular}

$\mathrm{B}=$ coefficient for the constant in the null model; S.E. = standard error around the coefficient for the constant; Wald = Wald $\chi^{2}$-test that tests the null hypothesis that the constant equals $0 ; \mathrm{df}=$ degrees of freedom; Sig. = significance ( $\mathrm{p}$ value); Exp $(\mathrm{B})=\operatorname{exponentiation}$ of the B coefficient (odds ratio)

going to the dentist much more frequently than clinical students ${ }^{7,15}$. This putting off going to the dentist by preclinical students was related to professional instruction on tooth brushing received less frequently and being less frequently told they brushed well ${ }^{7}$. On the contrary, the level of dental training did not influence the frequency of dental visits in our study, but significantly more final-year students received professional instructions on how to brush, and were told that they brushed well. Significantly more first-year students brushed their teeth with toothbrushes having hard bristles, and this pattern has been reported for the students in Britain, Turkey and Jordan as well ${ }^{15-17}$. According to the results of our study, Croatian students are not very much concerned about aesthetics, and less than $5 \%$ worry about the color of their teeth, unlike British students where $49 \%$ of first-year students and $26 \%$ of final-year students worry about the color of their teeth ${ }^{16}$. Anyway, the percentage of students checking their teeth in a mirror after brushing was relatively high, i.e. $65.6 \%$ and $74.5 \%$ for the first-year and sixth-year students, respectively.

The importance of dental plaque in the development of dental caries and periodontal diseases was confirmed in many studies, and proper oral hygiene plays a crucial role in their prevention ${ }^{20,21}$. Education for dental hygienist professionals has not yet been established in Croatia, therefore education of the general population on oral hygiene skills and oral health care lies entirely on dentists. During their studies, dental students should, besides receiving the knowledge on proper oral health care, get familiar with the techniques of motivating and conveying the knowledge on oral hygiene skills onto their patients. Some schools of medicine have introduced a motivational interviewing curriculum in their programs with an attempt to teach students behavior change skills. Motivational interviewing has been minimally studied in dental environment, but shows promise as a useful technique to help patients change their oral health behaviors ${ }^{22}$. Considering their education, personal oral hygiene of dental professionals is expected to be at a very high level. A study on how the knowledge obtained during undergraduate/graduate dental school training influences students' own oral health regimes could be indicative of the potential of the future professionals as motivators and educators of their patients.

Recent comparative studies between dental and other students at Zagreb University regarding oral health behavior and caries prevalence showed that dental students had significantly better oral health behavior and exhibited significantly lower DMFT and community periodontal index (CPI), although the DMFT was very high in both groups, i.e. 6.96 and 8.97 , respectively ${ }^{3}$. This could be attributed to ineffective preventive measures, and brings forward the problem of dental professionals focusing on treatment rather than effective prevention ${ }^{7}$.

Our study demonstrated that final-year students showed a significantly higher level of knowledge on oral health care issues, which further confirms the already pointed out importance of formal education of future dentists in the aspects of oral health care and prevention. Nevertheless, final-year students had a high plaque index, and it was utterly surprising that the knowledge and attitudes were not justified with proper oral hygiene. In two sextants, plaque indices were significantly higher than in their first-year counterparts. There are a few possible reasons for this result: (i) final-year students were more burdened with study- 
ing for exams, unlike first-year students who did not have exams during the research; (ii) entering new faculty and still clear decision to be occupied with oral health in their future, could be highly motivating for first-year students; and (iii) the knowledge on the chemistry of plaque, and demineralization-remineralization equilibrium could make the students believe that they are in control of these processes, and that until plaque is mature and metabolically active in fully anaerobic environment, they need not worry about the soundness of their hard dental tissues ${ }^{23}$. Nevertheless, it is hard to explain these inconsistencies and the reasons listed above should be considered only as an attempt to explain the unexpectedly poor oral hygiene among almost graduated dentists. Yildiz and Dogan ${ }^{17}$ compared self reported oral health behavior between pre-clinical and clinical dental students, and report higher gums bleeding among clinical students. Although they found it unexpected, the authors state that further studies which could relate self reported behavior with actual oral hygiene should be conducted. On the other hand, a number of reports on cross-cultural HU-DBI scores ${ }^{8-10,12}$ are concentrated on cultural differences and the dynamics of HU-DBI score improvement during dental training rather than comparing them with plaque score values.

Similar to our results, the study carried out by Rahman and $\mathrm{Kawas}^{24}$ also showed that motivation is almost as important as education for good oral hygiene. They conducted the study only among first-year students in the United Arabic Emirates and found that students who scored higher in HU-DBI questionnaire had higher plaque indices and gingival bleeding indices. The same dilemma as in our study arose which could bring about the trustworthiness of the self-evaluation questionnaire, since the self-evaluated oral health care habits are inconsistent with the actual oral state. Also, the consequence of wrongly estimated oral health care habits and the perception of personal oral hygiene as good could in the sixth-year students be the reason for visiting dental office less frequently ${ }^{10}$. Nevertheless, it has been reported that periodical reinforcements of preventive educational programs led to more reduced plaque indices than a preventive program carried out on one occasion ${ }^{25}$. It might therefore be that the preventive dentistry topics and oral health motivation should be incorporated in more curricula during undergraduate/graduate dental studies.

\section{Conclusions}

The increased HU-DBI score for the final-year students reflects the adoption of the concepts of prevention in oral health care, but the recorded lower level of oral hygiene suggests that the curriculum does not motivate them to practice self-oral care to a desired extent. Self-care should be more emphasized in the context of self benefit, as well as in the context of a dentist presenting a role model for his/her patients, and an educator on oral health care skills such as professional tooth brushing. The incorporation of preventive dental science and public health concepts in multiple curricula during dental studies might be motivating for self care regime among dental students.

\section{Acknowledgments}

The research reported here was supported by the Ministry of Science, Education and Sports, Republic of Croatia, Grant No. 065-0650445-0434.

\section{References}

1. Petersen PE, Bourgeois D, Ogawa H, Estupinan-Day S, Ndiaye C. The global burden of oral diseases and risks to oral health. Bull World Health Organ. 2005;83:661-9.

2. Bagramian RA, Garcia-Godoy F, Volpe AR. The global increase in dental caries. A pending public health crisis. Am J Dent. 2009;22:3-8.

3. Šimat S, Mostarčić KI, Matijević J, Simeon P, Grget Rošin K, Jukić Krmek S. A comparison of oral status of the fourth-year students of various colleges at the University of Zagreb. Acta Stomatol Croat. 2011;45:177-83.

4. Johanson CN, Osterberg T, Steen B, Birkhed D. Prevalence and incidence of dental caries and related risk factors in 70- to 76-year-olds. Acta Odontol Scand. 2009;67:304-12. http:// dx.doi.org/10.1080/00016350903054980

5. Par M, Badovinac A, Plančak D. Oral hygiene is an important factor for prevention of ventilator-associated pneumonia. Acta Clin Croat. 2014;53:72-8.

6. Bertolami CN. Rationalizing dental curriculum in the light of current disease prevalence and patient demand for treatment: form vs. content. J Dent Educ. 2001;65:725-35.

7. Peker K, Uysal O, Bermek G. Dental training and changes in oral health attitudes and behaviors in Istanbul dental students. J Dent Educ. 2010;74:1017-23.

8. Komabayashi T, Kawamura M, Kim KJ, Wright FA, Declerck D, Goisâs Mdo C, et al. The hierarchical cluster analysis of oral health attitudes and behaviour using the Hiroshima University-Dental Behavioural Inventory (HU-DBI) among final year dental students in 17 countries. Int Dent J. 2006;56:310-6. 
9. Kawamura M, Honkala E, Widström E, Komabayashi T. Cross-cultural differences of self-reported oral health behaviour in Japanese and Finnish dental students. Int Dent J. 2000; 50:46-50.

10. Polychronopolou A, Kawamura M. Oral self-care behaviours: comparing Greek and Japanese dental students. Eur J Dent Educ. 2005;9:164-70. doi:10.1111/j.1600-0579.2005.00387.x

11. Kawamura M, Sasahara H, Kawabata K, Iwamoto Y, Konishi K, Wright FA. Relationship between CPITN and oral health behaviour in Japanese adults. Aust Dent J. 1993;38:381-8.

12. Kawamura M, Iwamoto Y, Wright FA. A comparison of selfreported dental health attitudes and behavior between selected Japanese and Australian students. J Dent Educ. 1997;61:354-60.

13. Cortes FJ, Nevot C, Ramon JM, Cuenca E. The evolution of dental health in dental students at the University of Barcelona. J Dent Educ. 2002;66:1203-8.

14. Dumitrescu AL, Kawamura M, Sasahara H. An assessment of oral self-care among Romanian dental students using the Hiroshima University-Dental Behavioural Inventory. Oral Health Prev Dent. 2007;5:95-100.

15. Barrieshi-Nusair K, Alomari Q, Said K. Dental health attitudes and behaviour among dental students in Jordan. Community Dent Health. 2006;23:147-51.

16. Komabayashi T, Kwan SY, Hu DY, Kajiwara K, Sasahara H, Kawamura M. A comparative study of oral health attitudes and behaviour using the Hiroshima University-Dental Behavioural Inventory (HU-DBI) between dental students in Britain and China. J Oral Sci. 2005;47:1-7.

17. Yildiz S, Dogan B. Self reported dental health attitudes and behaviour of dental students in Turkey. Eur J Dent. 2011;5:253-9.

18. Malmö University Oral Health Database. Greene and Vermillion, 1964. Oral Hygiene Index-Simplified. At: http://www.
mah.se/CAPP/Methods-and-Indices/Oral-Hygiene-Indices/ Simplified-Oral-Hygiene-Index--OHI-S/. Accessed: April 30, 2014.

19. Kawamura M, Yip HK, Hu DY, Komabayashi T. A cross-cultural comparison of dental health attitudes and behaviour among freshman dental students in Japan, Hong Kong, and West China. Int Dent J. 2001;51:159-63.

20. Axelsson P, Nyström B, Lindhe J. The long-term effect of a plaque control program on tooth mortality, caries and periodontal disease in adults. Results after 30 years of maintenance. J Clin Periodontol. 2004,31:749-57. doi: 10.1111/j.1600-051 X.2004.00563.x

21. Kumar S, Konde S, Raj S, Agarwal M. Effect of oral health education and fluoridated dentifrices on the oral health status of visually impaired children. Contemp Clin Dent. 2012;3: 398-401. doi: 10.4103/0976-237X.107425.

22. White LL, Gazewood JD, Mounsey AL. Teaching students' behavior change skills: description and assessment of a new motivational interviewing curriculum. Med Teach. 2007;29: e67-71. doi: 10.1080/01421590601032443

23. Ten Cate JM, Larsen MJ, Pearce EIF, Fejerskov O. Chemical interactions between the tooth and oral fluids. In: Fejerskov $\mathrm{O}$, Kidd E (eds). Dental Caries. The Disease and Its Clinical Management. $2^{\text {nd }}$ ed. Tunbridge Wells: Gray Publishing; 2008; p. 209-32.

24. Rahman B, Kawas SA. The relationship between dental health behavior, oral hygiene and gingival status of dental students in the United Arab Emirates. Eur J Dent. 2013;7:22-7.

25. Rodrigues JA, dos Santos PA, Baseggio W, Corona SA, PalmaDibb RG, Garcia PP. Oral hygiene indirect instruction and periodic reinforcements: effects on index plaque in schoolchildren. J Clin Pediatr Dent. 2009;34:31-4.

Sažetak

\section{ZNANJE, STAVOVI I NAVIKE STUDENATA PRVE I ŠESTE GODINE STUDIJA DENTALNE MEDICINE SPRAM ORALNOG ZDRAVLJA}

\section{Lujo, M. Meštrovic, A. Ivanišević Malčić, Z. Karlović, J. Matijević i S. Jukić}

Svrha istraživanja bila je usporediti navike i znanja o oralnoj higijeni te indekse plaka studenata dentalne medicine prve i šeste godine. Upitnik Hiroshima University-Dental Behavioural Inventory (HU-DBI) ispunilo je 46,9\% studenata prve i $47 \%$ studenata šeste godine te im je određen indeks plaka. Podatci su obrađeni deskriptivnom statistikom, neparametrijskim testovima i korelacijskom analizom $(\mathrm{p}<0,05)$. Studenti šeste godine $(8,06)$ ostvarili su značajno bolji prosječni HU-DBI rezultat od studenata prve godine $(6,45)$. Značajno više studenata prve godine misli da ne može izbjeći umjetne zube u starosti $(\mathrm{p}=0,007)$, nikada nisu dobili profesionalni savjet kako četkati $(\mathrm{p}=0,019)$ i koriste tvrdu četkicu $(\mathrm{p}=0,001)$. Značajno više studenata šeste godine četka pažljivo svaki pojedini zub $(\mathrm{p}=0,008)$, misle da i bez paste mogu dobro očistiti zube $(\mathrm{p}=0,000)$, obojalo je zube detektorom plaka da vidi koliko su čisti $(\mathrm{p}=0,002)$, doktor ih je pohvalio da vrlo dobro četkaju zube $(\mathrm{p}=0,028)$. Indeks plaka bio je značajno bolji $(p<0,05)$ kod studenata prve godine $(7,94 \pm 0,72)$ u odnosu na studente završne godine $(9,13 \pm 0,77)$. Studij dentalne medicine pozitivno utječe na stajališta i znanja o oralnoj higijeni, no razina oralne higijene značajno se smanjila.

Ključne riječi: Studenti dentalne medicine; Oralno zdravlje; Ankete i upitnici; Zubni plak, indeks 